\title{
A Teologia da Libertação e a censura militar: as concepções políticas do jornal O São Paulo na década de 1970
}

DOI: $10.15175 / 1984-2503-202012302$

\author{
Fabio Lanza* \\ José Wilson Assis Neves Júnior ${ }^{* *}$
}

\section{Resumo}

O semanário católico O São Paulo sofreu a imposição da censura prévia durante o período de 1972 a 1978. Com a disponibilização virtual do seu arquivo particular de matérias vetadas pela ditadura militar (1964-1985) tornou-se possível analisar a perspectiva do catolicismo vinculado a Teologia da Libertação sob um novo prisma. A partir das contribuições da sociologia do conhecimento mainnheimiana e da análise documental sócio-histórica objetivou-se estudar as concepções políticas do catolicismo libertador nas páginas censuradas, com o intuito de determinar o seu "estilo de pensamento". Foi percebida a vinculação do meio de comunicação católico com uma vertente de pensamento liberal, limitada pela visão de mundo religiosa.

Palavras-chave: Sociologia do conhecimento; Igreja Católica; Teologia da Libertação; ditadura militar; censura.

La teología de la liberación y la censura militar: las concepciones políticas del periódico O São Paulo en la década de 1970

\section{Resumen}

El semanario católico O São Paulo sufrió la imposición de la censura previa durante el período de 1972 a 1978. Con la puesta a disposición virtual de su archivo particular de temáticas vetadas por la dictadura militar brasileña (1964-1985), es ahora posible analizar la perspectiva del catolicismo vinculado a la teología de la liberación bajo un nuevo prisma. A partir de las contribuciones de la sociología

\footnotetext{
* Doutor em Ciências Sociais pela Pontifícia Universidade Católica (PUC-SP). Professor Associado no Departamento de Ciências Sociais, do Programa de Pós-Graduação em Sociologia (M e D), do Programa de Mestrado Profissional em Rede Nacional de Ensino de Sociologia vinculados à Universidade Estadual de Londrina. Coordenador do Laboratório de Estudos sobre as Religiões e Religiosidades da UEL. E-mail: lanza1975@gmail.com. (1) https://orcid.org/0000-0003-2807-9075

** Doutorando pelo Programa de Pós-Graduação em Ciências Sociais da Unesp/Marília. Bolsista Capes. Mestre e bacharel em Ciências Sociais pela UEL. Pesquisador vinculado ao Laboratório de Estudos sobre Religiões e Religiosidades (LERR-UEL). E-mail: nevesjr1991@gmail.com. (1) https://orcid.org/0000-00030692-0740
} 
del conocimiento mainnheimiana y del análisis documental socio-histórico, se buscó estudiar las concepciones políticas del catolicismo libertador en las páginas censuradas, con la intención de determinar su estilo de pensamiento. Se concluye la existencia de un vínculo entre el medio de comunicación católico y una vertiente de pensamiento liberal, limitada por la visión religiosa del mundo.

Palabras clave: sociología del conocimiento; política; Iglesia católica; teología de la liberación; dictadura militar; censura.

\title{
Liberation Theology and military censorship: Political concepts in $O$ São Paulo newspaper in the 1970s
}

\begin{abstract}
From 1972 to 1978, Catholic weekly newspaper O São Paulo was subjected to prior censorship. With its private archive of material vetoed by the military dictatorship (1964-1985) now available online, it has been possible to analyze the perspective of Catholicism linked to Liberation Theology in a new light. Based on contributions from the Mannheimian sociology of knowledge and a sociohistorical analysis of documents, the aim was to study the political concepts of Libertarian Catholicism in the censured pages, in order to determine its style of thought. A link was perceived between the Catholic media and a strand of liberal thought limited by the vision of the religious world.
\end{abstract}

Keywords: Sociology of knowledge; politics; Catholic Church; Liberation Theology; military dictatorship; censorship.

\section{La théologie de la libération et la censure militaire : Les conceptions politiques de} I'hebdomadaire O São Paulo dans les années 1970

\section{Résumé}

De 1972 à 1978, l'hebdomadaire catholique O São Paulo a souffert de l'imposition d'une censure par anticipation. Avec la mise à disposition en ligne des articles censurés par la dictature militaire (1964-1985), on a pu analyser sous un nouveau prisme la perspective du catholicisme liée à la théologie de la libération. À partir des contributions de la sociologie de la connaissance chère à Mannheim et de l'analyse documentaire sociohistorique, notre objectif a été d'étudier les conceptions politiques du catholicisme libérateur dans les pages censurées de la revue et de déterminer ainsi son style de pensée. On a pu constater, dans la limite de la vision du monde permise par la religion, des liens entre ce média catholique et un courant de la pensée libérale

Mots-clés : Sociologie de la connaissance ; politique ; Église catholique ; Théologie de la libération ; dictature militaire ; censure.

\section{巴西解放神学和军人政权的审查：1970 年代天主教《圣保罗报》的政治观点}

\section{摘要:}

巴西天主教出版的周报《圣保罗》在 1972 年至 1978 年期间受到了军人政权(1964-1985) 的审查。 由于天主教会已经在网上公开了当年被军人审查机构禁止出版的那些文字资料，因此我们可以利用 这些资料分析天主教一些进步神父的解放神学思想。基于曼海姆 (Mainnheim) 知识社会学的理论， 作者对历史文献进行分析，目的是在被审查的和被禁止出版的文章中理解 “解放天主教” 的政治概 念及其思维方式。作者认为，巴西天主教媒体与自由主义思想的关系紧切，但是它的观点仍然受到 了宗教世界观的局限。 
关键字：知识社会学；政治；天主教会；解放神学；军事独裁；审查制度

\section{Introdução}

No ano de 2012 o projeto de pesquisa "Estudos sobre Religiosidades e Mídia Religiosa", protocolado no Centro de Letras e Ciências Humanas da Universidade Estadual de Londrina (CLCH-UEL), deu início ao empreendimento de preservação e publicização do arquivo de documentos e matérias vetadas, pela ditadura militar brasileira durante a década de 1970, do jornal católico O São Paulo ${ }^{1}$ - estabelecendo, para tanto, vínculos institucionais com o Núcleo de Documentação e Pesquisa Histórica da UEL (NDPH-UEL), a Pontifícia Universidade Católica (PUC-SP) e a Arquidiocese de São Paulo, entidade responsável pelo jornal O São Paulo.

As análises documentais elaboradas sobre o arquivo do semanário permitiram a problematização e elaboração do trabalho que buscou discernir os principais temas abordados pela Teologia da Libertação que sofreram repressão por parte da ditadura militar brasileira (1964-1985), vindo a determinar não somente a sua rotulação enquanto "subversivos" como também a imposição da censura prévia à imprensa escrita do catolicismo da libertação.

A opção pelas fontes documentais do semanário O São Paulo ocorreu por duas características principais: o longo período ao qual o meio de comunicação foi mantido velado pela censura prévia (1972-1978); ${ }^{2}$ e a sua condição enquanto um dos principais órgãos de comunicação da hierarquia católica libertadora brasileira, dentro do recorte temporal estudado - segundo Lanza (2006) é perceptível um processo de gradual adesão dos temas pertinentes à Teologia da Libertação pelo jornal católico paulistano, fenômeno que tem início no ano de 1967, com a chegada de Dom Paulo Evaristo Arns à equipe editorial, e se consolida de fato em 1970, com a nomeação de Arns para o cargo de Arcebispo da cidade de São Paulo. Destacando que a veiculação do ideário político-reflexivo nas páginas do jornal católico veio a determinar ascensão enquanto meio de comunicação de nível nacional, não estando mais restrito à um mero boletim paroquial.

Destaca-se que as análises documentais realizadas sobre as fontes documentais do semanário católico impuseram a pesquisa uma problemática a ser abordada, sendo

\footnotetext{
${ }^{1}$ Atualmente o Arquivo do semanário católico encontra-se disponível no formato digital para consulta pública em: http://www.uel.br/grupo-pesquisa/socreligioes/pages/paginas-censuradas-d-o-sao-paulo.php

${ }^{2}$ Conforme apresenta Aquino (1999) enquanto a maior parte da imprensa escrita brasileira foi dispensada da imposição da censura prévia militar a partir da abertura política, iniciada por Ernesto Geisel no ano de 1975, os jornais Movimento, Tribuna de Imprensa e O São Paulo permaneceram sob a tutela dos censores até o ano de 1978.
} 
que essa se constitui na percepção que o jornal apresenta a respeito da Teologia da Libertação, tendo em vista que o semanário expõe a preocupação com a necessidade de distinguir no catolicismo libertador

\begin{abstract}
O que é propriamente temática teológica, e a reflexão de cristãos em torno da libertação sócio-política. Esta última não é teologia da libertação, ainda que seja o material que alcança maior publicidade, sendo constituído em boa parte por documentos e manifestos de cristãos e sacerdotes "comprometidos". A confusão de ambos os níveis, a dos teólogos da libertação e dos cristãos e sacerdotes "comprometidos" com reflexão sócio-política ou denúncias proféticas, tem prejudicado a própria teologia da libertação, tornando-a objeto de críticas que não lhe competem, ou dando impressão de reduzi-la ao político, sem suficiente dimensão teológica e pastoral (GALILEIA, [1975?], laudas 4-5).
\end{abstract}

Nota-se, pois, uma visível preocupação do semanário católico em diferenciar sua proposição de atuação social político-religiosa dos setores do catolicismo libertador que se pretenderam precursores da mudança social a partir de um prisma teórico-referencial marxista. Esta problemática determinou a necessidade de classificar o estilo de pensamento que embasou a concepção de Teologia da Libertação do jornal O São Paulo considerando, ainda, as divergências existentes no campo das análises das Ciências Sociais quanto a esta classificação, tendo em vista que autores como Wanderley (2007) tenderam a classificar o movimento católico como progressista, enquanto uma outra vertente, como foi o caso de Martins (2011), afirma que esta classificação é um equívoco que só pode ser concebido se o pesquisador tomar como perspectiva analítica a própria tradição conservadora da Igreja Católica.

A pesquisa leva em consideração os apontamentos feitos por Mainwaring (2004) sobre o processo dialético de transformação ao qual as Instituições religiosas, enquanto partes inerentes da superestrutura, e a própria infraestrutura social encontram-se predispostas, sendo que as instituições sociais, incluindo a Igreja Católica, são inerentemente influenciadas e transformadas pelas mudanças sociais e pelas ideologias políticas que se instalam na sociedade. De acordo com o autor, assim como

Qualquer outra instituição, uma Igreja é influenciada pelas mudanças na sociedade em geral. Mais especificamente, argumento que ideologias políticas da sociedade brasileira tenham influenciado a concepção de fé da Igreja. Por sua vez, conflitos sociais, e a forma pela qual o Estado tentou resolvê-los ou suprimi-los, determinaram em grande escala essas ideologias e concepções da política. A luta política pode fazer com que as identidades sociais e as ideologias sejam repensadas, criando novas identidades e ideologias. De modo geral, as práticas sociais e as identidades institucionais não se modificam porque surgem novas ideias, mas, sim, porque o conflito social leva a uma nova maneira de compreender a realidade (MAINWARING, 2004, p. 25). 
Sendo ainda necessário destacar um preceito básico para a formulação de um estudo sobre a Igreja Católica, o de

\begin{abstract}
Impedir a atitude política bastante comum de aplicação de rótulos à Igreja Católica, como se eles fossem sintetizar o significado e as funções da instituição em todo o seu trajeto histórico. Dizer que a Igreja é instrumento de domesticação não basta, é necessário dizer de qual Igreja se fala. A Igreja das Comunidades Eclesiais de Base é a mesma Igreja dos Apostolados de Oração e das Filhas de Maria? Portanto, suas funções foram as mesmas?

O entendimento de que várias autocompreensões indicam a existência de Igreja diferentes inutiliza os rótulos e obriga ao estudo daquela Igreja específica, para se determinar quais foram as suas atitudes e o significado histórico (MANOEL, 2004, p. 9).
\end{abstract}

Desta forma o trabalho apresentado toma como fundamento teórico a análise realizada por Amaral (2010), que ao se apropriar das reflexões de Raymundo Faoro (2012) a respeito do Estado brasileiro, classifica a Igreja Católica enquanto um Grupo de Poder constituído por diferentes segmentos que representam interpretações particulares da realidade social, possibilitadas e limitadas por uma relativa autonomia reflexiva em relação aos princípios que garantem a coesão e continuidade existencial da Instituição religiosa. Considera-se, portanto, a partir de Mannheim (1981) que o estilo de pensamento, assim como a arte, representa um determinado grupo de indivíduos condicionados pelas especificidades do contexto social no qual se encontram inseridos.

Considera-se, também, uma diferenciação básica sobre a Igreja Católica brasileira em relação ao restante da América Latina, sendo que o caso brasileiro foi o único "do continente sobre a qual a teologia da libertação e seus seguidores das pastorais conseguiram exercer uma influência decisiva" (LÖWY, 2000, p. 135).

Define-se, então, que a análise documental, empreendida sobre as matérias censuradas do jornal O São Paulo, esteve embasada em uma perspectiva histórica que privilegiou compreender a maneira como as mudanças sociais vieram a fomentar e determinar as transformações no estilo de pensamento que representou a Teologia da Libertação nas páginas do semanário.

A classificação deste estilo de pensamento será realizada a partir dos princípios da Sociologia do Conhecimento de Mannheim (1981), segundo a qual os mesmos podem ser entendidos a partir de três tipologias orientativas básicas que podem, ou não, se correlacionar em determinados pontos em um mesmo estilo de pensamento, sendo elas: "tradicionalista", entendido enquanto uma reação fundamentada em tradições que se contrapõe momentaneamente às propostas de cunho progressista; "conservadorismo", exposto como processo reflexivo que parte da reação tradicionalista em processo dialético para com as proposições progressistas tendo por intuito às combater política e socialmente; e "pro- 
gressista", que se apresenta enquanto uma proposição que visa transformar a realidade social como um todo.

É importante, ainda, reforçar que a proposta deste trabalho reside na interpretação do estilo de pensamento da Teologia da Libertação veiculado estritamente nas páginas censuradas do jornal semanário O São Paulo, não deixando de considerar, contudo, que o catolicismo libertador se consolidou e foi entendido de forma plural e distinta em diferentes contextos e grupos sociais.

\section{Diretrizes e condicionantes da Teologia da Libertação no semanário O São Paulo}

As matérias censuradas, de forma prévia pela ditadura militar brasileira, do jornal católico paulistano se destacam historicamente pela visível tentativa de veiculação de formações político-ideológicas que representaram diferentes movimentos sociais do período, entre elas: Movimento Estudantil; Movimento Docente Universitário; Movimento Operário; grupos de juristas brasileiros; entre outros.

Esta perspectiva de valorização da pluralidade político-ideológica tem como ponto de partida a conscientização das distinções inerentes não só à Igreja Católica como também ao próprio catolicismo da libertação, assim em matéria vetada o jornal paulistano afirma que

A teologia da libertação não é uma escola uniforme, mas uma corrente pluralista, dentro do marco básico que temos apresentado sumariamente. Uns privilegiam mais os aspectos religiosos, outros temporais (especialmente políticos e culturais) da libertação. Nisso há uma fonte de confrontação que me parece positiva e que está permitindo um aprofundamento das diversas formas de libertação (GALILEIA, [1975?], lauda 9, grifo nosso).

Nota-se, pois, que o semanário O São Paulo concebe a Teologia da Libertação enquanto um movimento plural que deve atuar de forma condizente com a realidade na qual se encontra inserido, reforçando que o estabelecimento de diálogo entre diferentes formas de interpretar a realidade favorece a ampliação do processo compreensivo dos problemas sociais possibilitando, assim, uma melhor atuação crítica em prol de uma transformação social que supere a situação de desigualdade social.

Ademais deve se considerar que a equipe editorial do semanário paulistano se posicionou em defesa de que "não há verdadeira teologia da libertação sem encontro entre a libertação cultural, social, política, econômica e religiosa, e a salvação em Jesus Cristo" (GALILEIA, [1975?], lauda 5). 
Determinada afirmação exprime considerável valorização e concordância com as contradições inerentes aos diferentes grupos que compunham não só o movimento do catolicismo libertador como também a distinta realidade sócio-política latino-americana - o que chama a atenção para uma tendência analítica que se fundamenta de maneira aproximada para com as tendências democráticas liberais de reconhecimento da pluralidade política, que é sempre determinada e limitada pela concepção religiosa católica.

Salienta-se, nesse ponto, que existem determinadas peculiaridades essenciais da Igreja Católica que devem ser levadas em consideração quando se pretende analisa-la, entre elas destacamos a relativa autonomia que as instâncias nacionais, e mesmo regionais, recebem em relação ao Vaticano - sem deixar de considerar o extenso sistema hierárquico e burocrático no qual a Igreja Católica se fundamenta, o que possibilita que essa liberdade provincial seja garantida sem que, ao mesmo tempo, venha a proporcionar o rompimento com a sede internacional.

Dessa forma, afirma-se que a Igreja Católica, independentemente de sua autonomia provincial, tenderá, por primazia (mas não por obrigatoriedade), a articular-se com determinadas formações político-ideológicas no sentido de defesa da ordem social vigente no sistema internacional ao qual está vinculada, no caso em questão ao capitalismo internacional. O que implica na possibilidade de não aderir as demandas dos Estados nacionais nos quais encontra-se inserida, podendo vincular-se a distintos segmentos que compõe a realidade na qual se encontra inserida, sendo que, nesse caso, prevalecerá a sua autonomia provincial na determinação da função a ser exercida - encontrando tanto a possibilidade de agir a favor da ordem social instituída pelo regime vigente (como o exemplo da TFP dentro do contexto de ditadura militar) quanto a possibilidade de se fundamentar em exigências e recomendações de leituras particulares da sede no Vaticano (inserido em um sistema econômico internacional) para posicionar-se contra o regime político instituído (o caso do clero e laicato vinculado ao Centro Dom Vital). ${ }^{3}$

Destaca-se, ainda, uma tendência que pode ser observada quanto ao nível de autonomia relativa que é atribuída aos membros do clero católico de acordo com a posição que ocupa dentro da hierarquia da Igreja em relação ao Vaticano. É perceptível que quanto mais baixo o cargo exercido dentro da hierarquia católica, maior será o grau de auto-

\footnotetext{
${ }^{3}$ Os intelectuais católicos do Centro Dom Vital, com destaque para Jackson de Figueiredo, propunham a consolidação de uma contrarreforma que restaurasse o poder da Igreja Católica junto ao Estado brasileiro, consolidando assim uma ordem cristã. A perspectiva foi apoiada e defendida por membros de parcelas da hierarquia católica brasileira (VILLAÇA, 1974).
} 
nomia ideológica disponibilizado ao clérigo, já em contrapartida, conforme ascende dentro do sistema hierárquico do Vaticano, o membro da instituição começa a receber maiores atribuições quanto a função de manter a coesão dos dogmas entre os demais membros de suas instâncias de administração, de acordo com os dogmas vigentes no determinado contexto em que se encontram inseridos. ${ }^{4}$

Essa condição não implica na inexistência da possibilidade do efeito reverso, ou seja, é cabível do mesmo modo a inserção do baixo clero enquanto fiscalizador da autonomia ideológica interpretativa para com os demais membros do clero, podendo, em determinados casos, vir a denunciar clérigos de maior patente hierárquica.

Outro fato relevante na análise a respeito da autonomia relativa do clero católico se encontra na inserção provincial da Igreja, na qual o clérigo se encontra exercendo sua função, sendo que: quanto mais interiorana for a paróquia, menor tenderá a ser a pressão exercida pelo Vaticano para com essa localidade - contudo, não se deve deixar de levar em consideração que essa condição é extremamente delimitada pela relação estabelecida entre a paróquia local e a Diocese ou Arquidiocese à qual se encontra subordinada.

Assim, a proposição exposta pelo jornal O São Paulo em defesa da pluralidade político-ideológica pode, ainda, ser tomada enquanto fundamentação necessária para legitimar a própria coexistência do catolicismo da libertação, enquanto movimento recente de novas interpretações das diretrizes católicas. Desta forma a não valorização do pluralismo implicaria na definição da Igreja Católica enquanto um grupo coeso, rompendo com a autonomia relativa que possibilita às distintas parcelas do clero católico adaptar-se aos diferentes contextos sociais de forma a dar continuidade a sua missão evangelizadora.

Assim, tendo como premissa a sua missão evangelizadora e a necessidade de adequar-se às especificidades da realidade social na qual se insere o jornal O São Paulo define que

A Teologia da Libertação é sinal de um novo momento na História da Igreja da América Latina. Apresenta-se com a originalidade de incluir, como inerente, uma reflexão sobre a conjuntura histórica latino-americana. Distancia-se assim das escolas europeias e é a primeira a ser especificamente latino-americana, por dupla razão: porque seu conteúdo é a realidade particular da América Latina, e porque em seu método, inclui como ponto de partida, uma análise desta realidade realizada com o auxílio das ciências sociais (GALILEIA, [1975?], lauda 3).

\footnotetext{
${ }^{4}$ Essa afirmativa pode ser exemplificada com o caso da Esquerda Cristã Brasileira, no qual parcelas representantes do baixo clero nacional se vincularam aos movimentos católicos com grande influência socialista e, além de não receberem a adesão do alto clero, foram rapidamente sufocados pela hierarquia católica nacional, que julgou o movimento como dispare da doutrina social cristã (LÖWY, 2000).
} 
Ressalta-se neste ponto o destaque atribuído para o jornal católico no que tange as contribuições que as Ciências Sociais fornecem para a Teologia da Libertação para o processo de compreensão dos problemas sociais inerentes às mudanças sociais ocorridas na América Latina. É preciso considerar, contudo, que as teorias provenientes das Ciências Sociais são vistas pelo jornal paulistano como meras ferramentas que auxiliariam à missão evangelizadora do clero, não sendo cabível, portanto, que as reflexões sóciopolíticas se sobrepusessem à tarefa da Igreja.

Para compreender o novo modo de articulação dessa parcela clerical é necessário considerar o contexto social brasileiro, primeiramente levando em conta a forte política de industrialização empreendida pelo Estado brasileiro com o fim da segunda Guerra Mundial, e a consequente ampliação do processo de urbanização que determinaram a ascensão de movimentos sociais fortalecidos em meio à realidade nacional, ao passo em que favoreceram: o melhor delineamento das classes sociais brasileiras (IANNI, 1979) e a articulação de movimentos sociais por questões agrárias e de moradia (KOWARICK; BONDUKI, 1988).

Conforme apresentam Mainwaring e Krischke (1986), é notável a existência de uma forte tendência da hierarquia católica brasileira de manter-se em posicionamento favorável, e diretamente vinculada, ao Estado e ao regime partidário dominante até o Golpe de 1964. Assim, considera-se que os governos de Castelo Branco (1964-1967) e Costa e Silva (1967-1969) se constituíram enquanto divisores de águas na relação estabelecida entre uma parcela da hierarquia católica, pelo menos por parte dela, e os segmentos dominantes que compunham o Grupo no Poder.

Foi o processo de transformação das relações entre o clero católico brasileiro para com o Estado e a sociedade civil que resultou na ascenção da Teologia da Libertação na América Latina - dentro dessa nova perspectiva católica, adotada por uma parcela do clero latino americano, a Igreja abria mão de sua condição histórica de articulações com as elites sociais, passando a se posicionar em defesa dos membros da sociedade civil menos abastados e perseguidos pelas elites dominantes (WANDERLEY, 2007).

Essa mudança de posicionamento, contudo, não se constitui como um fato ao acaso, mas como resultado de um processo histórico de mudanças sociais que possibilitaram, e até mesmo exigiram, essas transformações nas relações da Igreja Católica para com a sociedade, principalmente quando analisamos o caso particular do Brasil. Ressaltando que para o semanário católico a Igreja

É apanhada de cheio pelo fenômeno da urbanização. Temos que estar alertas para as linhas de crescimento ou antes de inchação de nossas cidades. Estamos longe 
das tranquilas e quase imóveis paróquias do passado. Temos de partir, quando preciso, para deslocamentos de campos de ação. Temos que criar estilos novos e vias novas para a evangelização de sempre (EVANGELIZAÇÃO..., 1976, lauda 8)

O texto enviado por D. Hélder Câmara, para publicação no semanário católico paulistano, reforça a noção da necessidade que se coloca perante a Igreja Católica latinoamericana de se adaptar à nova realidade que lhe é imposta, para que se possa dar continuidade a sua missão evangelizadora.

A partir desses novos delineamentos sociais, decorrentes da industrialização e urbanização de determinados polos nacionais, nota-se, no início da década de 1960, uma mudança nas articulações das massas populares, levando, ainda, em consideração o desencadeamento da crise política que fomentou uma maior politização da população brasileira (IANNI, 1979) - a crise política e o processo de gradual politização das massas se intensificaram cada vez mais durante o exercício do governo João Goulart (1961-1964), passando a se mobilizar em prol das propostas de reforma de base feitas pelo plano de governo de Jango.

Estas transformações ocorridas no modo como as massas brasileiras agiam politicamente veio a condicionar que determinados setores dirigentes da sociedade brasileira, com destaque para o segmento militar, se mobilizassem em combate as perspectivas progressistas que começavam a tomar forma na sociedade brasileira.

Neste ponto, se faz necessário abordar as contribuições de Raymundo Faoro (2012) a respeito das peculiaridades do Estado brasileiro, que, segundo o autor, se constitui historicamente enquanto fundamentado em princípios do patrimonialismo, no qual diferentes segmentos dirigentes passam a compor um Grupo no Poder, concebendo o aparato estatal enquanto entidade mantenedora de seus interesses particulares. Assim as mudanças sociais ocorridas no Brasil são realizadas a partir de modelos de modernização, impostos de cima para baixo, de modo a atender as demandas político-econômicas destes segmentos, salientando ainda o papel de destaque atribuído pelo autor ao segmento militar no que tange ao direcionamento destes processos de modernização.

Dentro desta perspectiva deve-se considerar, também, as contribuições feitas por Furtado (1964) no que diz respeito aos baixos níveis de democracia de dinamismo social que decorrem do modelo de Estado brasileiro, que em decorrência da característica diretiva e particularista de setores dominantes alheios a população como um todo passa a se embasar em um modelo de capitalismo politicamente orientado. Ressaltando, ainda, o papel exercido pela difusão, empreendida pelos Estados Unidos da América (EUA), de uma perspectiva dicotômica de divisão de mundo, decorrente do estabelecimento do con- 
flito da Guerra Fria, que se exacerba no ano de 1959 em decorrência da Revolução Cubana (FURTADO, 1985).

Assim, com a concretização do Golpe militar de 1964, e o regime político instaurado em decorrência, teve início uma transformação nas relações estabelecidas entre o poder público e a sociedade civil, que culminaram na perseguição e extinção dos movimentos sociais populares (KOWARICK; BONDUKI, 1988) que passaram a encontrar, na Igreja Católica libertadora, o último reduto possível para dar continuidade as suas pautas e lutas.

Destaca-se, então, que a Teologia da Libertação se constituiu enquanto forma de adequação de parcelas da Igreja Católica brasileira aos problemas sociais característicos do período em questão, fenômeno que, conforme apresenta Wanderley (2007), se consolida a partir do Concílio Vaticano II (1962-1965) e das Conferências Episcopais de Medellín (1968) e Puebla (1979), a partir dos quais parcelas da Igreja Católica latino-americana passam a reinterpretar o evangelho de forma a se posicionar em favor dos oprimidos sociais (pobres, jovens, trabalhadores, perseguidos políticos, entre outros).

\section{Alcances e limitações propostos pelo jornal para as reflexões sócio-políticas da Igreja}

Apesar de apresentar uma proposta de valorização da pluralidade políticoideológica, como chave para a solução dos problemas sociais, o jornal O São Paulo tece constantes críticas aos extremismos ideológicos, desde o comunismo soviético até a doutrina de Segurança Nacional. Dentro desta perspectiva são expostas críticas em relação às tendências políticas voltadas para o radicalismo de esquerda (marxista) em matéria vetada que aborda o movimento estudantil (ME) paulista. O texto apresenta preocupação para com um dos grupos que compunha o ME, denominado "Liberdade e Luta", que demonstrava exacerbado "vanguardismo", propondo "se colocar na direção de um movimento de massa capaz, em poucos dias, de mudar radicalmente a situação política do país", e insistindo "em teses gerais e em chavões que acabavam por resultar [em] vazios" (O MOVIMENTO..., entre 1976 e 1978, não paginado), as críticas seguem abordando a visível capacidade exposta pelo grupo em manipular as decisões das assembleias estudantis, gerando, assim, resultados que não condiziam com as reais demandas do movimento como um todo. A matéria finaliza enaltecendo a "vitória esmagadora" da União Estadual do Estudantes (UEE) contra o grupo radicalista, o que, nas palavras do semanário, exprimia "a orientação ponderada da maioria dos estudantes, capaz de participar com maturidade e sem histerismos, da vida política nacional". 
Em matéria que trata do discurso proferido por D. Hélder Câmara na Filadélfia (EUA), no ano de 1976, o arcebispo reflete e rebate as críticas proferidas contra a Teologia da Libertação a respeito de sua rotulação enquanto "subversiva" e marxista; D. Hélder destaca sua surpresa para com a astúcia intelectual da oposição ao se afirmarem "defensores da civilização cristã" no combate às infiltrações marxistas dentro da própria lgreja. Contudo ele rebate as falas acusações afirmando que as mesmas "não devem atemorizar os cristãos. 'Não precisa de marxismo quem tem o Evangelho, o Vaticano II e Medellín. Não precisa de Marx quem tem Jesus Cristo" (FILADÉLFIA, 18 ago. 1976, lauda 6).

O mesmo posicionamento é exposto por Dom Hélder em matéria enviada pelo mesmo para publicação no jornal católico paulistano. O texto discorre a respeito dos problemas socioeconômicos que assolavam o nordeste brasileiro da época, em dado momento, o arcebispo de Olinda começa a questionar a tendência de "reconhecer ao Estado o direito de julgar nossa missão evangelizadora, incriminando-a de subversão ao comunismo. É muito cômodo procurar encobrir assim a denúncia de injustiças que oprimem a maior parte de nossa gente", reforçando ainda que "perigoso como ser ingênuo diante o comunismo é aceitar a taxação de comunismo" (EVANGELIZAÇÃO..., 1976, lauda 6).

Notemos que as palavras de Dom Hélder reforçam o posicionamento da hierarquia católica em relação à Teologia da Libertação, ao passo em que não concebe o cristianismo libertador como vinculado a qualquer tipo de movimento marxista (socialista ou comunista), refutando, de maneira incisiva, qualquer possível acusação. Para a elite eclesiástica, que representava essa vertente do clero, os membros do movimento eram tidos como detentores da missão profética de lutar em prol dos Direitos Humanos (ONU-1948) - relembrando que, conforme apresenta Mannheim (1981), os direitos universais do homem são a expressão máxima e o fundamento de qualquer estilo de pensamento de embasamento liberal.

O próprio jornal faz uma síntese da perspectiva defendida pela hierarquia eclesiástica que compõe a Teologia da Libertação, desvinculando sua rotulação enquanto "subversiva" ao comunismo, ao passo em que "considerada ao nível de sua hierarquia a Igreja Católica não se apresenta revolucionária: ela se recusa a retomar a análise marxista da sociedade" (NA AMÉRICA..., maio 1976, não paginado).

Em outra matéria vetada, o jornal define que, ao desvincular-se de teorias embasadas na análise ideologizada da realidade social (que partem do pressuposto de enquadrar a realidade dentro de uma modelo; em detrimento de construir o modelo, ou defini-lo a partir da própria realidade), a Teologia da Libertação encontra a possibilidade de "evitar a 
cilada de uma teologia 'ideologizada', e manter seu nível profético, dentro do qual os cristãos de diversas opções ideológicas poderão encontrar-se" (GALILEIA, [1975?], lauda 6). Percebe-se, assim, que a adesão de uma perspectiva liberal que valoriza a coexistência da pluralidade social permite uma ampliação agregadora de diferentes segmentos sociais favorecendo a missão evangelizadora católica.

Desta forma, o jornal católico paulistano empreende sua luta política pautado na defesa dos Direitos Humanos (ONU-1948), assim, no que tange aos direitos dos trabalhadores o semanário afirma que

A Declaração Universal dos Direitos do Homem, proclamada pela ONU em 1948, afirma, em seu artigo $23, \S 4^{\circ}$, que o princípio da liberdade sindical constitui uma liberdade fundamental do homem, sendo parte integrante da liberdade de associação, esta prevista no artigo 20.

Trata-se, pois, de um direito fundamental do homem a ser respeitado por todos e pelo Estado.

É a Organização Internacional do Trabalho (O.I.T.), órgão especializado da Organização das Nações Unidas (O.N.U.) em questões do trabalho, com sede em Genebra, que define o que seja liberdade sindical.

A OIT definiu o que seja liberdade sindical através de uma convenção internacional, aprovada em congresso no qual tomaram parte os países membros, compostos por representantes governamentais, dos patrões e dos trabalhadores.

A convenção intencional que definiu a liberdade sindical foi basicamente a convenção do número 87 de 1948 .

A convenção 87 protege dois princípios básicos da liberdade sindical: o direito de cada um sindicalizar-se e a independência do sindicato em relação ao Estado.

Todos os países membros da OIT deveriam aplicar em seu direito interno esses princípios básicos da liberdade sindical. Infelizmente, porém, alguns países, valendo-se do princípio da soberania nacional, deixam de aplicá-los internamente. É o caso dos países do Leste Europeu, isto é, dos países ligados ao pacto de Varsóvia, sob a liderança da União Soviética. É o caso também do nosso Brasil, cujos sindicatos estão sob a tutela governamental (LIBERDADE..., [set. 1977?], não paginado). ${ }^{5}$

Outra matéria vetada que exemplifica essa perspectiva liberal de defesa dos direitos universais do homem debate a respeito da necessidade de universalização desses direitos em meio a sociedade brasileira, problematizando o fato de que

As leis não defendem o direito dos pobres. Mas, assim mesmo, nosso povo luta por seus direitos; até mesmo pelo direito de ter direitos.

O lavrador é gente igual aos outros. Quando ele exige os seus direitos não está pedindo esmolas, não. Está querendo uma coisa sua, que alguns estão roubando ou querendo só pra eles (DECLARAÇÃO..., 1 mar. 1978, lauda 1). ${ }^{6}$

Reafirmando ainda seu posicionamento em defesa da Declaração dos Direitos Humanos (ONU-1948), a qual defendendo que:

\footnotetext{
${ }^{5} \mathrm{O}$ documento citado não possui nenhum tipo de definição de sua autoria, a data precisa de redação, também não foi disponibilizada.

${ }^{6} \mathrm{~A}$ matéria possui referência quanto à sua autoria restrita ao nome "Marcelo".
} 
A liberdade, a justiça e a paz haveriam de construir um mundo de bem-estar e felicidade ao ser humano, firmaram:

Que todos os homens nascem livres e iguais em dignidade e direitos à vida, à liberdade e à segurança, sem nenhuma distinção de cor, raça, crença ou opinião política. (DECLARAÇẪO..., 1 mar. 1978, lauda 2).

Notemos, pois, o posicionamento assumido pelo semanário católico em defesa dos direitos universais da classe trabalhadora em nível legal e internacional, proveniente das declarações universais produzidas em um contexto político-liberal globalizante póssegunda Guerra Mundial. Partindo dessa perspectiva, podemos, então, aferir que o jornal O São Paulo não se posiciona como subversivo questionando a ordem social capitalista, pelo contrário: ele assume e incorpora ao movimento do catolicismo libertador a vertente liberalista, que caracteriza o capitalismo hegemônico internacional, levantando sua bandeira na luta contra as formações estatais de caráter extremista - ao passo em que, mais uma vez, o jornal católico se coloca em oposição aos regimes de extrema direita (ditaduras fascistas e militares) e de extrema esquerda (socialismo soviético).

Ademais, a leitura da matéria comemorativa de $1^{\circ}$ de maio faz constante referência à necessidade de uma vinculação da união proletária (limitada a uma perspectiva liberal de direitos trabalhistas, sindicais e grevistas) para com as diretrizes do Evangelho. Nesse sentido, a matéria segue explicitando que:

Diante de uma situação injusta, contrária aos direitos humanos, contrária aos ensinamentos do Evangelho que nos convidam à solidariedade, à justiça, não podemos ficar com os braços cruzados. É preciso construir nossa união. Cada trabaIhador precisa conversar com o outro, sobre a situação. Nossa força está em nossa união. Pequenos grupos na empresa, nos bairros, nossa presença nos sindicatos, irão, aos poucos, a indiferença, a desconfiança, o medo.

Neste $1^{\circ}$ de maio de 1977 apelamos, pois, a todos os trabalhadores, nossos companheiros, para que estejamos unidos, nos organizemos nas empresas sindicatos e bairros, a fim de aprofundarmos nossos conhecimentos sobre a realidade e sobre as condições que a classe tem para encontrar soluções adequadas.

Que lutemos juntos para criar um sistema não só com base no egoísmo econômico e, sim, no respeito a pessoa humana (IGREJA..., 1 maio 1977, laudas 2-3).

A análise desses documentos nos permite perceber determinada vinculação entre a perspectiva teórico-social defendida pelo jornal católico para com os princípios do Estado de Direito, democrático liberal, da Teoria da Justiça de John Rawls (2008), embasada na definição de dois princípios fundamentais de justiça que exprimem a necessidade de existência de uma diferenciação na distribuição de bens e riquezas que devem, contudo, coexistir com uma perspectiva de igualdade de condições para a competição entre os diferentes indivíduos que compõem a sociedade, prevalecendo as capacidades e habilidades do sujeito, salientando que "a concepção geral de justiça não impõe restrições quanto 
aos tipos de desigualdades permissíveis; ela só exige que a situação de todos melhore" (RAWLS, 2008, p. 76). É importante destacarmos que

\begin{abstract}
Posições como as de Rawls se encaixam perfeitamente em posições do tipo Teologia da Libertação, CPT e MST. Os discursos se aproximariam bastante, embora as consequências políticas possam ser diferentes. O problema reside não somente no refinamento da análise filosófica, na medida em que Rawls sustenta que a liberdade deve ser antes de tudo preservada, mas no modo como ideias morais adentram o espaço público, sustentadas por organizações políticas, como movimentos sociais, Igreja ou partidos políticos (ROSENFIELD, 2010, p. 161).
\end{abstract}

Percebe-se, dessa forma, que diferentes movimentos sociais brasileiros, entre eles os vinculados ao catolicismo libertador, sofreram influência da perspectiva da justiça social rawlsiana, passando a apropriar-se de particularidades dessa corrente teórica de acordo com as demandas específicas que representavam seus segmentos.

Notemos, por exemplo, que a matéria "Igreja no mundo do trabalho, Pastoral Operária" não chega em nenhum momento a questionar a divisão social antagônica em si, se mantendo em oposição às injustiças decorrentes do egoísmo econômico que gera a extrema concentração de renda, o que determinaria a continuidade da incapacitação da livre competição de determinadas parcelas sociais. Existe, portanto, concordância para com o preceito da existência de uma "desigualdade social razoável" que seja limitada pela primazia da manutenção do "bem comum" e, nessa perspectiva, "as desigualdades sociais e econômicas devem estar dispostas de tal modo que tanto (a) se possa razoavelmente esperar que se estabeleçam em benefício de todos como (b) estejam vinculadas a cargos e posições acessíveis a todos" (RAWLS, 2008, p. 73).

Um dos exemplos ilustrativos para fundamentarmos a proposta acima se encontra disponível em uma das matérias vetadas do semanário O São Paulo, que aborda a comemoração de primeiro de maio destacando os problemas sociais impostos aos trabalhadores brasileiros. O jornal problematiza que:

Basta ter olhos para se ver a situação. É claro que o trabalhador está sendo explorado. O salário que recebemos não é suficiente para nossas necessidades básicas. Não existe estabilidade no emprego e o trabalhador é despedido sem motivo. A participação na empresa não existe. Não temos nem voz nem voto. De modo geral, a própria estrutura e finalidade da empresa não respondem as necessidades do bem comum. As máquinas sem vida são tradas melhores do que nós, pessoas humanas, feitas à imagem e semelhança de Deus. Os sindicatos estão afastados de sua finalidade de luta pelos verdadeiros direitos dos trabalhadores. Graves são os problemas de transporte, habitação, saúde...[sic] Como o salário normal é insuficiente, grande parte dos trabalhadores é obrigada a trabalhar de 10 a 13 horas por dia, inclusive aos sábados e feriados. Isto significa a destruição da grande conquista da classe trabalhadora: a jornada de 8 horas que deu origem ao dia $1^{\circ}$ de Maio (IGREJA..., 1 maio 1977, lauda 2). 
Notemos, portanto, o apontamento feito pelo jornal católico a respeito da necessidade de um Estado de Direito que regule as demandas sociais que estavam colocadas para os trabalhadores brasileiros da época: baixos salários; alto custo de vida; inexistência de um sindicato ativo que estabeleça o dialogo real entre trabalhadores e empregadores; ineficácia do sistema de transporte; problemas habitacionais; ineficácia do sistema de saúde; extensão da jornada de trabalho.

Atentemo-nos ao fato de que todos os problemas levantados pelo jornal O São Paulo a respeito da realidade, na qual o trabalhador brasileiro se encontrava inserido, são demandas que foram gradualmente assimiladas pelas formulações liberais a respeito dos direitos universais do homem, desde suas primeiras formulações - e que fazem parte da Declaração Universal dos Direitos Humanos (ONU-1948).

Assim, ao fomentar a união proletária em prol da conscientização e união da categoria enquanto movimento social, não implica em demandar a organização revolucionária do segmento social, ao passo em que se apropriam do standard da mobilização em defesa dos direitos humanos fundamentais, opondo-se exclusivamente aos extremismos da concentração de bens e poder impostos a realidade social brasileira do período histórico no qual se encontram inseridos.

O semanário mantém, portanto, uma posição em defesa de uma mobilização social, de caráter liberalista, que garanta uma melhor igualdade social para os segmentos da sociedade civil brasileira - neste ponto é preciso considerar os apontamentos de Faoro (2012) sobre o fato de que o liberalismo político no Brasil se consolidou, historicamente, enquanto fundamentado em uma perspectiva conservadora que teve por intuito implementar um modelo de "modernização" que tanto adequa-se a realidade social e econômica do país para a situação internacional quanto possibilita-se a continuidade da relação de dominação patrimonialista do Estado.

Ressalta-se, também, o posicionamento assumido pela Teologia da Libertação em prol da urgência de uma reforma agrária na sociedade brasileira, conforme apresenta uma das matérias vetadas do semanário O São Paulo, referindo-se ao problema de, em média, onze milhões de famílias de agricultores brasileiros sem posses de terras,

A Comissão [Pastoral de Terra] defende a necessidade urgente de uma reforma agrária ampla, para dar terra a estas famílias - ou evitar que lhes seja tomada, quando já a têm. Chama a atenção pelo fato de que o Brasil, quinto maior país do mundo, tem terra suficiente para todos. Segundo a CPT o governo poderia ter evitado muitos casos de violência se tivesse interferido em resposta aos apelos de socorro.

Mas nem todos estão satisfeitos com o ativo interesse da lgreja pelos problemas de terra. O presidente da Confederação Nacional da Agricultura, que representa os 
grandes fazendeiros - $\mathrm{n}$ - sua maioria criadores de gado - acaba de acusar a Igreja de tentar provocar desordem no campo, e estimular os posseiros a invadirem as terras. Houve casos de prisões de padres, acusados de subversão, quando tentaram defender os posseiros (PASTORAL..., [entre 1972 e 1978], laudas 1-2).

Atentemos ao fato de que, ao posicionar-se em defesa das demandas populares por uma reforma agrária, os membros da Teologia da Libertação foram mais uma vez rotulados como subversivos a ordem, o que implicava, no contexto político-social da ditadura militar (1964-1985), na subsequente vinculação do grupo aos ideais marxistas/socialistas/comunistas. O fato se torna contraditório a partir do momento em que analisamos a perspectiva da reforma agrária pelo viés liberal da Teoria da Justiça raw/siana, tendo em vista que, conforme apresenta Leite Filho (2012), a distribuição de terras, ou reforma agrária, é um dos princípios para o estabelecimento do Estado de Direito, fundamentado no preceito da justiça social, que viabilizará, futuramente, a livre competição econômica entre os membros da sociedade civil, sendo que prevalecerá nessa competição as potencialidades e capacidades individuais dos sujeitos que compõe a sociedade.

Outro ponto importante para o debate a respeito da condicionalidade da perspectiva católica para o apoio dos movimentos sociais reside no posicionamento do jornal católico em defesa e valorização dos movimentos feministas que começam a ganhar espaço na sociedade brasileira do século XX, relembrando o trecho grifado: "nota-se nesses dez anos após Medellín, a importância que têm tomado os movimentos feministas: procuram colocar em evidência o lugar e a função da mulher na formação social" (OS BISPOS..., [1978?], lauda 2, grifo nosso), ${ }^{7}$ contudo, mais uma vez o apoio ofertado pela Igreja paulistana demonstra limitações impostas pela visão de mundo religiosa cristã. Um exemplo claro dessa perspectiva analítica se encontra na leitura de outra matéria vetada, intitulada "Os trabalhadores e a situação econômica" (OS TRABALHADORES..., 21 abr. 1977), na qual a equipe editorial do semanário se situa em oposição à realidade social brasileira, decorrente da crise e dos baixos salários, que resultava na necessidade da esposa deixar a casa e os filhos para ir trabalhar.

Dessa maneira, quando analisamos a visível limitação da perspectiva liberal exposta pelas matérias censuradas do jornal católico paulistano, se torna perceptível que a classificação da Teologia da Libertação, enquanto um movimento de caráter "progressista", não passa de "uma designação inventada por partidos de esquerda, sem o devido co-

\footnotetext{
${ }^{7} \mathrm{~A}$ matéria citada se encontra consideravelmente desgastada pelo tempo, não possuindo qualquer registro preciso de data de produção, tendo sua autoria reservada ao codinome "GG".
} 
nhecimento do ideário católico e de sua doutrina social, que os fazem progressistas no marco da tradição conservadora própria da Igreja" (MARTINS, 2011, p. 25).

É importante nos remetermos, nesse momento, às classificações realizadas por Mannheim (1981), a respeito da conceituação dos termos reformismo conservador e reformismo progressista. Segundo o autor,

O reformismo conservador consiste na substituição de fatores individuais por outros fatores individuais ("melhoramentos"). O reformismo progressista tende a dar conta de um fato indesejável reformando todo mundo ao redor que torna sua existência possível. Assim, o reformismo progressista ataca o sistema como um todo, enquanto que o reformismo conservador ataca detalhes particulares (MANNHEIM, 1981, p. 102).

A perspectiva mainnheimiana nos coloca em uma situação complicada de conceituação do tipo de movimento que se consolida com o catolicismo libertador, ao passo em que, quando consideramos, especificamente, a conjuntura político-social brasileira, ${ }^{8} \mathrm{e}$ mesmo a tradição conservadora da Igreja Católica Romana, encontramos a possibilidade de classificar o catolicismo da Libertação enquanto um movimento "reformista progressista”. Contudo, se partirmos de uma perspectiva analítica internacional, embasada na Declaração Universal dos Direitos Humanos, não poderemos atribuir à Teologia da Libertação nenhum tipo de classificação que supere os fundamentos de um reformismo conservador (focado em particularidades da realidade social que necessitam de "melhorias"). Problematizando, ainda, o fato de que, tendo o Brasil assinado a Declaração dos Direitos Humanos (ONU-1948), a Igreja libertadora não fez nada mais do que cobrar direitos legais que deveriam ser garantidos à população brasileira, apresentando somente algumas demandas particulares de "melhorias".

\section{Considerações finais}

O trabalho apresentado buscou classificar o modo como a Teologia da Libertação foi compreendida pelas páginas, censuradas pela ditadura militar, do jornal católico O São Paulo (1972-1978), tendo em vista não só as divergências bibliográficas no que tange à atribuição dos títulos de "progressista" ou "conservadora", mas considerando também o fato do catolicismo da libertação ter se constituído enquanto um movimento plural que se

\footnotetext{
${ }^{8}$ Conforme apresentado anteriormente, a conjuntura brasileira, construída até o período estudado, se caracterizava pela exclusão da participação política da sociedade civil como um todo, estando restrita às classes dirigentes e abastadas que a compunham, salientando a quase inexistência de determinados direitos fundamentais exigidos pela Declaração Universal dos Direitos Humanos (ONU-1948), como é o exemplo do sindicalismo.
} 
desenvolveu de maneiras distintas de forma a adequar-se as especificidades contextuais nas quais se inseriu.

A pesquisa documental empreendida embasou-se em uma perspectiva históricosociológica de análise que privilegiou a compreensão do modo como as mudanças sociais e as transformações dos estilos de pensamento se encontram inseridos em um processo dinâmico-dialético de constante transformação - sendo válido afirmar que as mudanças na infraestrutura compelem adequações por parte da superestrutura, do mesmo modo que o oposto também é válido.

Demonstrou-se que o semanário paulistano concebeu a Teologia da Libertação a partir das fundamentações de uma perspectiva político-social liberal, com destaque para as reflexões rawlsianas, que se encontrava, contudo, limitada pela visão de mundo religiosa, tendo em vista que a autonomia relativa do clero, condição que favorece a missão evangelizadora, será sempre restringida pela garantia da continuidade de uma coesão básica entre as diferentes formas de pensamento que assumem em decorrência da adaptação aos contextos no quais se inserem.

A partir das contribuições da Sociologia do Conhecimento mainnheimiana o trabalho apresentou a impossibilidade de classificar o catolicismo libertador do jornal O São Paulo pelos conceitos puros de "progressismo" e "conservadorismo", afirmando que a atribuição da tipologia ocorre de acordo com a perspectiva analítica do pesquisador, que pode classificar este estilo de pensamento de duas formas: "reformista progressista", no que tange às origens conservadoras do liberalismo brasileiro e da própria Igreja Católica; ou "reformista conservador", quando se toma como prisma analítico o liberalismo em nível internacional.

\section{Fontes}

DECLARAÇÃO ao povo brasileiro. O São Paulo, 1 mar. 1978. Disponível em: https://drive.google.com/file/d/OBzFtoWP2meSFWTBXWFFQSERZRGM/view. Acesso em: 19 fev. 2016.

EVANGELIZAÇÃO de Olinda. O São Paulo, 1976. Disponível em: https://drive.google.com/file/d/0BzFtoWP2meSFOXIUeWRjY2RKNU0/view. Acesso em: 17 fev. 2016.

FILADÉLFIA. O São Paulo, 18 ago. 1976. Disponível em: https://drive.google.com/file/d/0BzFtoWP2meSFZ2pFek52dHVBemM/view. Acesso em: 16 fev. 2016.

GALILEIA, Segundo. [A libertação na Conferência de Medellín]. O São Paulo, [1975?]. Transcrição de artigo traduzido e publicado pelos Cadernos do CEAS, 34: 56-61. 
Salvador, Centro de Estudos e Ação Social, nov.-dez., 1974. Disponível em: https://drive.google.com/file/d/0BzFtoWP2meSFWjFfM3FUODhLLXM/view. Acesso em: 23 fev. 2016.

IGREJA no mundo do trabalho, Pastoral Operária. O São Paulo, 1 maio 1977. Disponível em: https://drive.google.com/file/d/0BzFtoWP2meSFeElzR2NrUXRRYnM/view. Acesso em: 23 fev. 2016.

LIBERDADE sindical: direito fundamental. O São Paulo, set. 1977. Disponível em: https://drive.google.com/file/d/0BzFtoWP2meSFUXRLbWxGN2xPRGM/view. Acesso em: 21 mar. 2016.

NA AMÉRICA Latina: os cristãos entre a ditadura e a revolução. O São Paulo, maio 1976. Disponível em: https://drive.google.com/file/d/0BzFtoWP2meSFSE1nUEdKTVdfQ1k/view. Acesso em: 4 fev. 2016.

[O Movimento Estudantil (ME) depois de vários anos desarticulado, voltou à existência por ocasião da morte de Vladimir Herzog em novembro de 1975]. O São Paulo, [entre 1976 e 1978]. Não paginado. Disponível em: https://drive.google.com/file/d/0BzFtoWP2meSFNXBmdGZEdEtacnM/view. Acesso em: 25 fev. 2016.

OS BISPOS vão discutir em Puebla. O São Paulo, [1978?]. Disponível em: https://drive.google.com/file/d/0BzFtoWP2meSFR1A2VFJCR1c0dE0/view. Acesso em: 17 fev. 2016.

OS TRABALHADORES e a situação econômica. O São Paulo, 21 abr. 1977. Disponível em: https://drive.google.com/file/d/OBzFtoWP2meSFTOthd3hRQzVIbDA/view. Acesso em: 23 fev. 2016.

PASTORAL na BBC. O São Paulo, [entre 1972 e 1978]. Disponível em: https://drive.google.com/file/d/0BzFtoWP2meSFdEtfbC0zR0ZwR0E/view. Acesso em: 22 mar. 2016.

\section{Referências}

AMARAL, Roniere R. Milagre político: catolicismo da libertação. São Paulo: Annablume, 2010.

AQUINO, Maria Aparecida. Censura, imprensa, Estado Autoritário (1968-1978): o exercício cotidiano da dominação e da resistência - O Estado de São Paulo e Movimento. Bauru: EDUSC, 1999.

FAORO, Raymundo. Os donos do poder. formação do patronato político brasileiro. São Paulo: Globo, 2012.

FURTADO, Celso. Dialética do desenvolvimento. 2. ed. Rio de Janeiro: Fundo de Cultura, 1964.

FURTADO, Celso. A fantasia organizada. 5. ed. Rio de Janeiro: Paz e Terra, 1985. 
IANNI, Octávio. Estado e planejamento econômico no Brasil. 3. ed. Rio de Janeiro: Civilização Brasileira, 1979.

KOWARICK, Lúcio; BONDUKI, Nabil. Espaço urbano e espaço político: do populismo a redemocratização. In: KOWARICK, Lúcio (Org.). As lutas sociais e a cidade. Rio de Janeiro: Paz e Terra, 1988. p 133-168.

LANZA, Fábio. Matrizes ideológicas dos arcebispos paulistanos (1956-85): um olhar sob o prisma do semanário O São Paulo. 2006. Tese (Doutorado em Ciências Sociais)-Pontifícia Universidade Católica de São Paulo, São Paulo, 2006..

LEITE FILHO, Antonio Henriques Lemos. Reforma agrária e justiça social no campo: elementos para uma abordagem a partir da teoria da justiça de John Rawls. 2012. Dissertação (Mestrado em Direito Agrário)-Universidade Federal de Goiás, Goiânia, 2012.

LÖWY, Michael. A Guerra dos deuses: religião e política na América Latina. Petrópolis: Vozes, 2000.

MAINWARING, Scott. Igreja Católica e política no Brasil 1916-1985. São Paulo: Brasiliense, 2004.

MAINWARING, Scott; KRISCHKE, Paulo J. (Org.). A Igreja nas bases em tempo de transição (1974-1985). Porto Alegre: L\&PM, 1986.

MANNHEIM, Karl. O pensamento conservador. In: MARTINS, José de Sousa (Org.). Introdução crítica a sociologia rural. São Paulo: Hucitec., 1981. p. 77-131.

MANOEL, Ivan A. O Pêndulo da História: tempo e eternidade no pensamento católico (1800-1960). Maringá: Eduem, 2004.

MARTINS, José de S. A política do Brasil: lúmpen e místico. São Paulo: Contexto, 2011.

RAWLS, John. Uma teoria da justiça. 3. ed. São Paulo: Martins Fontes, 2008.

ROSENFIELD, Denis. Justiça, Democracia e Capitalismo. Rio de Janeiro: Elsevier, 2010.

VILLAÇA. Antonio Carlos. História da questão religiosa no Brasil. Rio de Janeiro: Francisco Alves, 1974.

WANDERLEY, Luiz E. Democracia e Igreja Popular. São Paulo: EDUC, 2007. 